Phinisi Integration Review
Vol. 3, No.2, Agustus 2020 Hal 215-222
Website: http://ojs.unm.ac.id/pir
p-ISSN: $2614-2325$ dan e-ISSN: 2614-2317
DOI: https://doi.org/10.26858/v3i2.14884

\title{
Pengaruh Mentoring Dosen Pembimbing Akademik terhadap Prestasi Akademik Mahasiswa STKIP Pembangunan Indonesia
}

\author{
Harti Oktarina ${ }^{1}$, Sitti Hajar Aswad ${ }^{2}$ \\ ${ }^{12}$ STKIP Pembangunan Indonesia/Pendidikan Ekonomi \\ Email: ${ }^{1 h o . o k t a r i n a @ g m a i l . c o m ~}$
}

\begin{abstract}
Abstrak. Penelitian ini bertujuan untuk: (1) mengetahui bagaimana mentoring dosen pembimbing akademik mahasiswa Program studi Pendidikan Ekonomi angkatan 2016 STKIP Pembangunan Indonesia, (2) mengetahui bagaimana prestasi akademik mahasiswa Program studi Pendidikan Ekonomi angkatan 2016 STKIP Pembangunan Indonesia, (3) mengetahui bagaimana pengaruh mentoring dosen pembimbing akademik terhadap peninngkatan prestasi akademik mahasiswa program studi pendidikan ekonomi angkatan 2016 STKIP Pembangunan Indonesia. dalam penelitian ini adalah mahasiswa program studi pendidikan ekonomi angkatan 2016 yang berjumlah 17 orang. Teknik pengumpulan data dengan menggunakan kuesioner. Teknik analisis data menggunakan analisis regresi linier sederhana dengan bantuan program SPSS. Hasil penelitian menunjukkan bahwa Mentoring dosen pembimbing akademik di program studi pendidikan ekonomi angkatan 2016 termasuk dalam kualifikasi cukup dalam pengaruhnya terhadap peningkatan prestasi akademik. Prestasi akademik mahasiswa di prodi pendidikan ekonomi angkatan 2016 termasuk dalam kualifikasi sedang. Hal ini nampak pada hasil rata-rata prestasi belajar mahasiswa adalah 3,66 terletak pada interval 3,51 - 4,00 dan termasuk tingkat kualifikasi Cum Laude. Terdapat pengaruh antara mentoring dosen pembimbinga akademik terhadap prestasi akademik mahasiswa program studi pendidikan ekonomi anagkatan 2016 STKIP Pembangunan Indonesia. Hal ini ditunjukkan dari nilai sig. 0,007 $<0,05$ maka Ha diterima dan Ho ditolak.
\end{abstract}

Kata Kunci: Mentoring; Dosen; Mahasiswa

\begin{abstract}
This study aims to: (1) find out how the implementation of academic guidance for students of the 2016 STKIP Pembangunan Indonesia Economic Education study program, (2) find out how the academic achievements of the STKIP 2016 Indonesian Economic Education Study Program, (3) find out how the influence of academic guidance to the improvement of academic achievement of students of the 2016 STKIP Pembangunan Indonesia economic education study program. in this study were 17 students of the 2016 economic education study program. Data collection techniques using a questionnaire. Data analysis techniques using simple linear regression analysis with the help of the SPSS program. The results showed that the Mentoring of academic supervisors in the 2016 class of economic education study program was included in the qualification sufficiently in its effect on improving academic achievement. Student academic achievements in the 2016 economic education study program included in the medium qualification. This can be seen in the average results of student learning achievement is 3.66 located at intervals of 3.51 - 4.00 and including Cum Laude qualification level. There is an influence between the mentoring lecturers of academic advisers on the academic achievements of students of the 2016 Economic Education Study Program STKIP Pembangunan Indonesia. This is indicated by the value of sig. $0.007<0.05$ then $\mathrm{Ha}$ is accepted and Ho is rejected
\end{abstract}

Keywords: Mentoring; Lecture; Student 


\section{PENDAHULUAN}

Mahasiswa sebagai agen of change, atau penerus dan pembuat perubahan untuk bangsa, memiliki peran yang besar untuk bangsa, banyak sejarah dimasa lampau yang dicetak atau di prakarsai oleh pemuda (mahasiswa). Idealnya mahasiswa menjadi panutan masyarakat dengan keilmuan dan perilakunya. Sebagaimana mahasiwa yang nantinya melanjutkan tonggak perjuangan dan pemimpin bangsa hendaknya memiliki integritas dan kapasitas yang mendukung. Seiring dengan tuntutan dunia usaha terhadap kesiapan dan kualitas para lulusan perguruan tinggi ini, akhirnya mendorong setiap perguruan tinggi memperbaiki sistem pembelajaran dan kurikulum pendidikannya serta menata sistem penjaminan mutu pendidikan yang diberikan pada pihak yang berkepentingan (stake holders). Usaha peningkatan kualitas pendidikan tinggi tersebut adalah para mahasiswa dituntut untuk meningkatkan kualitas pembelajaran, berkomitmen untuk menunjukkan prestasi belajar yang lebih baik.

Kualitas mahasiswa dapat dilihat dari prestasi belajar aatau prestasi akademik yang diraihnya. (Moh. Zaiful Rosyid, Mustajab 2019) mengatakan Prestasi dalam belajar adalah hasil dari pengukurn terhadap peserta didik yang meliputi faktor kognitif, afektif dan psikomotorik setelah mengikuti proses pembelajaran yang diukur dengan menggunakan instrument tes yang relevan. Nilai - nilai hasil belajar mahasiswa yang dilambangkan dengan Indeks Prestasi baik IP semester atau IP kumulatif merupakan tolak ukur keberhasilan mahasiswa tersebut. Thompson dalam (Suprihatin 2017) mengemukakan bahwa banyak faktor yang mempengaruhi kesuksesan akademik, diantaranya menejemen waktu (goal setting), nasehat atau bimbingan akademik, stress dan integrasi institusi. Menurut Hollis dalam (Suprihatin 2016), pembimbing akademik untuk setiap mahasiswa memegang kunci untuk kemajuan dengan pembinaan mahasiswa melalui pilihan pendidikan umum, seleksi mata kuliah, maupun pemilihan matakuliah minor.

Bimbingan akademik adalah salah satu aspek yang sangat penting bagi pengalaman mahasiswa selama menempuh kuliah di perguruan tinggi. Pembimbing akademik adalah dosn yang ditetapkan oleh Pimpinan Universitas untuk melaksanakan tugas membimbing mahasiswa (Susilowati 2008). Salah satu peran ideal dosen pembimbing akademik adalah sebagai mentor bagi mahasiswa bimbingannya. Dalam memberikan dukungan untuk pilihan akademik mahasiswa, mentor mampu mempresentasikan atas mahasiswa mengenai kekuatan, kelemahan, kemampuan mereka serta mendukung pembuatan perencanaan tujuan pencapaian akademik masing-masing mahasiswa (Crips dan Cruz dalam Pranatasari 2014). Dalam fungsi ini, mentor melakukan eksplorasi ketertarikan, kemampuan, dan kepercayaan mahasiswa berkaitan dengan akademik mereka. Dengan adanya dosen pembimbing akademik diharapkan mahasiswa dapat lulus sesuai dengan target atau tepat waktu.

Berdasarkan latar belakang diatas, maka peneliti tertarik melaksanakan penelitian mengenai : "Pengaruh Mentoring Dosen Pembimbing Akademik terhadap Prestasi Akademik Mahasiswa Program Studi Pendidikan Ekonomi STKIP Pembangunan Indonesia".

Secara umum penelitian ini bertujuan untuk: 1) mengetahui bagaimana mentoring dosen pembimbing akademik mahasiswa Program studi Pendidikan Ekonomi angkatan 2016 STKIP Pembangunan Indonesia, (2) mengetahui bagaimana prestasi akademik mahasiswa Program studi Pendidikan Ekonomi angkatan 2016 STKIP Pembangunan Indonesia, (3) mengetahui bagaimana pengaruh mentoring dosen pembimbing akademik terhadap peninngkatan prestasi akademik mahasiswa program studi pendidikan ekonomi angkatan 2016 STKIP Pembangunan Indonesia.

\section{METODE}

Jenis penelitian yang digunakan dalam penelitian ini bersifat deskriptif kuantitatif yang implikasinya akhirnya menggambarkan hubungan antara pelaksanaan kegiatan bimbingan akademik dengan prestasi belajar peserta didik dengan metode ex-post facto. Populasi dalam penelitian ini adalah mahasiswa program studi pendidikan ekonomi angkatan 2016 yang berjumlah 112 orang. maka peneliti 
mangambil sampel sebesar $15 \%$ dari jumlah populasi yang ada. Sehingga sampel dalam penelitian ini adalah $15 \%$ X $112=16,8$ atau 17 orang mahasiswa. Mahasiswa yang menjadi sampel penelitian dengan jumlah 17 orang ini merupakan mahasiswa yang telah melaksanakan kegiatan bimbingan akademik. Metode pengumpulan data dalam penelitian ini menggunakan (a) Kuesioner digunakan untuk mengumpulkan data mengenai variabel pelaksanaan bimbingan akademik mahasiswa Program studi Pendidikan Ekonomi Angkatan 2016 STKIP Pembangunan Indonesia, (b) Wawancara dilakukan untuk mengumpulkan data mengenai variabel pelaksanaan kegiatan bimbingan akademik, dan (c) Dokumentasi digunakan dengan tujuan memperoleh data mengenai variabel terikat Prestasi Belajar Mahasiswa, yakni IPK (Indeks Prestasi Kumulatif) mahasiswa Program studi Pendidikan Ekonomi Angkatan 2016 STKIP Pembangunan Indonesia serta data tentang jumlah mahasiswa dan penasehat akademik di Program studi Pendidikan Ekonomi Angkatan 2016 STKIP Pembangunan Indonesia.

Uji validitas dan reabilitas dilakukan peneliti untuk menguji layak atau tidaknya item pertanyaan yang diajukan kepada responden. Apabila dikatakan valid dan reliabel, maka penelitian dapat dilanjutkan ketahapan selanjutnya. Uji validitas dilakukan dengan menggunakan rumus Pearson Product Moment. Dengan bantuan SPSS akan didapatkan hasil pengujian validitas dimana nilai validitas yang kuat jika Nilai Sig. (2-tailed) $<0,05$ dan
Pearson Correlation bernilai positif,maka item soal angket tersebut valid, namun, jika Nilai Sig. (2-tailed) $<0,05$ dan Pearson Correlation bernilai negative maka item soal angket tersebut tidak valid (Sudarmanto 2013).

Uji reabilitas dilakukan dengan cara membandingkan niai cronbach alpha dengan ketentuan cronbach alpha minimal 0,60. Artinya jika nilai cronbach alpha yang didapatkan dari hasil perhitungan spss lebih besar dari 0.60 maka disimpulkan kuesioner tersebut reliable (Nasution 2012).

Analisis statistik deskriptif adalah statistik yang digunakan untuk menganalisis data dengan cara mendeskripsikan atau berupa tabel distribusif frekuensi dan mean score yang digunakan untuk mengukur mentoring bimbingan akademik dan prestasi belajar mahasiswa berdasarkan data yang telah diperoleh dari objek penelitian (Siregar 2017).

Statistik inferensial berfungsi untuk menguji kebenaran. Dalam hal ini akan dilakukan pengujian hipotesis (Muchson n.d.). Uji hipotesis dilakukan dengan analisis regresi sederhana dan koefesien determinasi untuk mengetahui hubungan fungsional atau pengaruh antara dua variabel yang ada.

\section{HASIL DAN PEMBAHASAN}

\section{Uji Validitas dan Uji Reabilitas}

Berikut adalah hasil uji validitas dan uji reabilitas dengan menggunakan SPSS 20

Tabel 1. Uji Validitas

\begin{tabular}{ccccc} 
Item & $\begin{array}{c}\text { Pearson } \\
\text { Correlation }\end{array}$ & Sig. (2-tailed) & Keputusan & Kesimpulan \\
P1 & 0.588 & 0.013 & $0.013>0.05$ & Valid \\
P2 & 0.540 & 0.036 & $0.036>0.05$ & Valid \\
P3 & 0.534 & 0.027 & $0.027>0.05$ & Valid \\
P4 & 0.565 & 0.018 & $0.018>0.05$ & Valid \\
P5 & 0.527 & 0.030 & $0.030>0.05$ & Valid \\
P6 & 0.514 & 0.029 & $0.029>0.05$ & Valid \\
P7 & 0.693 & 0.002 & $0.002>0.05$ & Valid \\
P8 & 0.582 & 0.014 & $0.014>0.05$ & Valid \\
P9 & 0.525 & 0.024 & $0.024>0.05$ & Valid \\
\hline
\end{tabular}

Sumber : olah data penelitian dengan SPSS 20

Berdasarkan hasil olah data diatas menunjukkan nilai pearson correlation untuk semua item bernilai positif dengan nilai sig. (2tailed) kurang dari nilai alpha (0.05). berdasarkan hal tersebut maka dapat disimpulkan semua item pertnyaan yang berkaitan dengan mentoring dosen pembimbing dinyatakan valid 
Tabel 2. Hasil uji reabilitas

Reliability Statistics

\begin{tabular}{r|lr}
\hline \multicolumn{1}{r|}{ Cronbach's Alpha } & \multicolumn{2}{|c}{ N of Items } \\
\hline .655 & \\
\hline
\end{tabular}

Sumber : olah data SPSS 20

Berdasarkan tabel output diatas diketahui $\mathrm{N}$ of items (banyaknya item atau pertanyaan angket) sebanyak 9 butir item dengan nilai cronbach's alpha sebesar 0.665. karena nilai cronbach's alpha $0.665>0.60$ maka sebagaimana dasar pengambilan keputusan dalam uji reabilitas, dapat disimpulkan bahwa seluruh item pertanyaan angket untuk variabel mentoring dosen pembimbing akademik adalah reliable atau konsisten.

\section{Analisis Statistik Deskriptif}

a. Mentoring Dosen Pembimbing Akademik Setelah menyebarkan angket kepada mahasiswa program studi Pendidikan Ekonomi angkatan 2016 sebanyak 17 orang yang merupakan sampel dari penelitian ini terkait tentang mentoring Dosen pembimbing akademik program studi Pendidikan Ekonomi angkatan 2016, peneliti memperoleh respon yang beragam. Adapun hasilnya dapat dilihat pada tabel berikut:

Tabel 3. Hasil Uji Analisis Deskripttif

\section{Descriptive Statistics}

\begin{tabular}{|c|c|c|c|c|c|}
\hline & $\mathrm{N}$ & Minimum & Maximum & Mean & Std. Deviation \\
\hline Mentoring_DosenPA & 17 & 30.00 & 41.00 & 36.9412 & 2.98895 \\
\hline Valid N (listwise) & 17 & & & & \\
\hline
\end{tabular}

Hasil perhitungan statistik deskriptif tentang mentoring dosen pembimbing akademik program studi pendidikan ekonomi angkatan 2016 STKIP Pembangunan Indonesia memiliki nilai rata-rata 36,9412 . Nilai standar deviasi yang diperoleh sebesar 2,98895, angka ini menunjukkan penyimpangan nilai-nilai data dengan nilai rata-rata dari keseluruhan data. Jadi, angka ini menunjukkan ukuran penyebaran data nilai angket variabel dosen pembimbing akademik mahasiswa pendidikan ekonomi angkatan 2016.

Adapun kategorisasi pelaksanaan bimbingan akademik, nilai-nilai batas klasifikasinya adalah:

$\mathrm{A}=\mathrm{X}+1,5 \mathrm{SD}=36,94+1,5(2,98)=41,42$

$\mathrm{B}=\mathrm{X}+1 \mathrm{SD}=36,94+2,98=39,92$

$\mathrm{C}=\mathrm{X}-1 \mathrm{SD}=36,94-2,98=33,95$

$\mathrm{D}=\mathrm{X}-1,5 \mathrm{SD}=36,94-1,5(2,98)=32,45$

Dengan demikian nilai-nilai batas interval klasifikasinya adalah:

Tabel 4. Kategorisasi Mentoring Dosen Pembimbing Akademik

\begin{tabular}{llcc}
\hline \multicolumn{1}{c}{ Klasifikasi } & \multicolumn{1}{c}{ Interval nilai } & Frekuensi & Persentase \\
\hline Sangat baik & Diatas 41,43 & 0 & $0 \%$ \\
Baik & $39,93-41,42$ & 3 & $17,65 \%$ \\
Cukup & $33,96-39,92$ & 11 & $64,71 \%$ \\
Kurang baik & $32,46-33,95$ & 2 & $11,76 \%$ \\
\hline Sangat kurang baik & Dibawah 32,45 & 1 & $5,88 \%$ \\
\hline
\end{tabular}

Sumber: hasil olah data kategorisasi mentoring dosen pembimbing akademik

Hasil perhitungan statistik deskriptif mentoring dosen pembimbing akademik mahasiswa program studi Pendidikan Ekonomi angkatan 2016 STKIP Pembangunan Indonesia diperoleh nilai rata-rata yaitu 36,94 berada pada interval 33,96 - 39,92 sehingga berada pada 
kategori cukup. Artinya mentoring dosen pembimbing akademik termasuk dalam kualifikasi cukup dalam pengaruhnya terhadap peningkatan prestasi belajar. Berdasarkan tabel di atas, diperoleh bahwa persepsi mahasiswa terkait mentoring dosen pembimbing akademik yang berada pada kategori sangat kurang baik sebanyak 1 orang $(5,88 \%)$, persepsi mahasiswa yang berada pada kategori kurang sebanyak 2 orang $(11,76 \%)$, persepsi mahasiswa yang berada pada kategori cukup sebanyak 11 orang $(64,71 \%)$, persepsi mahasiswa yang berada pada kategori baik sebanyak 3 orang $(17,65 \%)$.

b. Prestasi akademik mahasiswa program studi pendidikan ekonomi STKIP Pembangunan Indonesia

Hasil perhitungan statistik deskriptif prestasi akademik dapat dilhat pada tabel berikut :

Tabel 5. Hasil perhitungan statistic deskriptif prestasi akademik

Descriptive Statistics

\begin{tabular}{|c|c|c|c|c|c|}
\hline & $\mathrm{N}$ & Minimum & Maximum & Mean & Std. Deviation \\
\hline Prestasi_akademik & 17 & 3.09 & 3.97 & 3.6576 & .23493 \\
\hline Valid N (listwise) & 17 & & & & \\
\hline
\end{tabular}

Tabel diatas menunjukkan nilai rata-rata prestasi akademik mahasiswa program studi pendidikan ekonomi angkatan 2016 STKIP Pembangunan Indonesia sebesa 3,6576. Standar deviasi yang diperoleh sebesar 0,23493. Angka ini menunjukkan penyimpangan nilai-nilai data dengan nilai rata-rata dari keseluruhan data. Jadi, angka 0,23493 menunjukkan ukuran penyebaran data nilai indeks prestasi mahasiswa.

Adapun kategorisasi prestasi belajar, nilainilai batas klasifikasinya adalah:

Tabel 6. kategorisasi prestasi akademik mahasiswa

\begin{tabular}{clcc}
\hline Interval & \multicolumn{1}{c}{ Kategori } & Frekuensi & Persentase \\
\hline $3,51-4,00$ & Cum laude & 12 & $70,59 \%$ \\
$3,01-3,50$ & Sangat memuaskan & 5 & $29,41 \%$ \\
$2,76-3,00$ & Memuaskan & 0 & $0 \%$ \\
$<2,75$ & Cukup & 0 & $0 \%$ \\
& Jumlah & 17 & $100 \%$ \\
\hline
\end{tabular}

Sumber : hasil olah data prestasi akademik mahasiswa

Hasil perhitungan statistik deskriptif prestasi akademik mahasiswa jurusan Pendidikan Ekonomi angkatan 2016 STKIP Pembangunan Indonesia diperoleh nilai rata-rata yaitu 3,6576 berada pada interval 3,51-4,00 sehingga berada pada kategori Cum Laude. Persentase mahasiswa yang berada pada kategori cukup mencapai $0 \%$. Persentase mahasiswa yang berada pada kategori memuaskan mencapai $0 \%$. Persentase mahasiswa yang berada pada kategori sangat memuaskan mencapai 29,41\% dengan jumlah 5 orang. Persentase mahasiswa yang berada pada kategori Cum Laude mencapai $70,59 \%$ dengan jumlah 12 orang. c. Uji Regresi Linier Sederhana

Uji regresi digunakan untuk meramalkan suatu variabel dependen (Y) berdasar satu variabel independen $(\mathrm{X})$ dalam suatu persamaan linear. Untuk menguji ada tidaknya pengaruh antara mentoring pembimbing Akademik dengan prestasi belajar, maka dapat diperoleh dari hasil penelitian diolah dengan analisis menggunakan metode statistik yaitu analisis persamaan regresi sederhana. Formula persamaan linear:

Tabel 7. Hasil Uji Regresi Linier 


\begin{tabular}{|c|c|c|c|c|c|c|}
\hline \multirow[t]{2}{*}{ Model } & & \multicolumn{2}{|c|}{ Unstandardized Coefficients } & \multirow{2}{*}{$\begin{array}{c}\begin{array}{c}\text { Standardized } \\
\text { Coefficients }\end{array} \\
\text { Beta } \\
\end{array}$} & \multirow[t]{2}{*}{$\mathrm{t}$} & \multirow[t]{2}{*}{ Sig. } \\
\hline & & $\mathrm{B}$ & Std. Error & & & \\
\hline \multirow{2}{*}{1} & (Constant) & 1.831 & .585 & & 3.132 & .007 \\
\hline & Mentoring_DosenPA & .049 & .016 & .629 & 3.134 & .007 \\
\hline
\end{tabular}

a. Dependent Variable: Prestasi akademik

Sumber : olah data SPSS

Tabel Cofficients memaparkan nilai konstanta a dan $b$ dari persamaan linear.

Interpretasi :

$$
Y=1,831+0,049 X
$$

a. Konstanta sebesar 1,831 artinya jika tidak ada mentoring dari dosen pembimbing akademik maka prestasi akademik mahasisawa program studi pendidikan ekonomi angkatan 2016 STKIP
Pembangunan Indonesia hanya sebesar 1,831 ;

b. Jika ada peningkatan mentoring dosen pembimbing akademik sebesar $1 \%$ maka akan meningkatkan prestasi akademik mahasisawa program studi pendidikan ekonomi angkatan 2016 STKIP Pembangunan Indonesia akan meningkat sebesar 0,0049 .

Tabel 8. Hasil uji hipotesis

\begin{tabular}{|c|c|c|c|c|c|c|}
\hline \multicolumn{7}{|c|}{ ANOVA $^{a}$} \\
\hline Model & & Sum of Squares & $\mathrm{df}$ & Mean Square & $\mathrm{F}$ & Sig. \\
\hline \multirow{3}{*}{1} & Regression & .349 & 1 & .349 & 9.823 & $.007^{\mathrm{b}}$ \\
\hline & Residual & .534 & 15 & .036 & & \\
\hline & Total & .883 & 16 & & & \\
\hline
\end{tabular}

a. Dependent Variable: Prestasi_akademik

b. Predictors: (Constant), Mentoring_DosenPA

Sumber : data diolah dengan program SPSS

a. Hipotesis

Ho : Mentoring dosen pembimbing akademik tidak berpengaruh signifikan terhadap prestasi akademik mahasiswa program studi Pendidikan Ekonomi angkatan 2016 STKIP Pembangunan Indonesia

$\mathrm{Ha}$ : Mentoring dosen pembimbing akademik berpengaruh signifikan terhadap prestasi akademik mahasiswa program studi Pendidikan Ekonomi angkatan 2016 STKIP Pembangunan Indonesia

b. Kriteria pengujian

Jika nilai sig. $>$ nilai alpha $(0,05)$, maka

Ho diterima dan Ha ditolak

Jika nilai sig. $<$ nilai alpha $(0,05)$, maka $\mathrm{Ha}$ diterima dan Ho ditolak

c. Kesimpulan

Tabel diatas menunjukkan nilai sig. $0,007<$ 0,05 maka Ha diterima dan Ho ditolak. Jadi dapat disimpukan bahwa Mentoring dosen pembimbing akademik berpengaruh signifikan terhadap prestasi akademik mahasiswa program studi Pendidikan Ekonomi angkatan 2016 STKIP Pembangunan Indonesia.

\section{Pembahasan}

Setelah melakukan serangkaian penelitian untuk mengetahui pengaruh mentoring dosen pembimbing akademik terhadap prestasi akademik mahasiswa program studi pendidikan ekonomi angkatan 2016 STKIP Pembangunan Indonesia diketahui bahwa mahasiswa jurusan rogram studi pendidikan ekonomi angkatan 2016 STKIP Pembangunan Indonesia ada 17 orang yang terdeteksi telah melaksanakan mentoring dengan dosen pembimbing akademik. Hasil penelitian sebaran angket mengenai pelaksanaan kegiatan mentoring dengan dosen pembimbing akademik memberikan output yakni persepsi mahasiswa terkait bimbingan akademik pada kategori 
sangat kurang baik sebanyak 1 orang $(5,88 \%)$, persepsi mahasiswa yang berada pada kategori kurang sebanyak 2 orang $(11,76 \%)$, persepsi mahasiswa yang berada pada kategori cukup sebanyak 11 orang $(64,71 \%)$, persepsi mahasiswa yang berada pada kategori baik sebanyak 3 orang $(17,65 \%)$. Diperoleh nilai rata-rata yaitu 36,94 berada pada interval 33,96 - 39,92 sehingga berada pada kategori cukup

Berdasarkan hasil sebaran angket mengenai mentoring dengan dosen pembimbing akademik, ada beberapa hal terkait bimbingan akademik yang perlu ditingkatkan, seperti: Dosen Penasehat Akademik harus mengevaluasi hasil kuliah semseter sebelumnya serta memberikan bimbingan akademik untuk semester selanjutnya setiap awal semester. Selain itu, Penasehat Akademik juga harus selalu memantau keadaan mahasiswa bimbingannya minimal 2 kali dalam satu semester. Sementara hal-hal yang perlu dipertahankan seperrti: Penasehat Akademik selalu memberikan bimbingan, arahan, dan saran, Penasehat Akademik selalu menetapkan dan mengumumkan jadwal bimbingan setiap awal semester, serta Penasehat Akademik sering menanyakan proses dan keadaan Akademik mahasiswa bimbingannya.

Berdasarkan hasil pengujian hipotesis diperoleh nilai sig. 0,007 $<0,05$ maka Ha diterima dan Ho ditolak. Jadi dapat disimpukan bahwa Mentoring dosen pembimbing akademik berpengaruh signifikan terhadap prestasi akademik mahasiswa program studi Pendidikan Ekonomi angkatan 2016 STKIP Pembangunan Indonesia. Hal tersebut sejalan dengan penelitian (Susilowati 2008) bahwa peran pembimbing akademik meliputi sebagai sumber informasi, membantu dalam usaha penyelesaian dan pemberi petunjuk dan saran kepada mahasiswa seta memantau kegiatan belajar mahasiwa bimbingannya dapat membuat mahasiswa berprestasi dengan lebih baik.

\section{SIMPULAN DAN SARAN}

Berdasarkan uraian hasil penelitian diatas, dapat disimpulkan bahwa : (1) Mentoring dosen pembimbing akademik di programstudi pendidikan ekonomi angkatan 2016 STKIP Pembangunan Indonesia termasuk dalam kualifikasi cukup dalam pengaruhnya terhadap peningkatan prestasi akademik. Hal ini nampak pada hasil angket yang dibagikan yakni hasil rata-rata bimbingan akademik adalah 36,94 berada pada interval 33,96 - 39,92 dimana hasil ini tergolong pada kategori cukup; (2) Prestasi akademik mahasiswa di prodi pendidikan ekonomi angkatan 2016 STKIP Pembangunan Indonesia termasuk dalam kualifikasi sedang. Hal ini nampak pada hasil rata-rata prestasi belajar mahasiswa adalah 3,66 terletak pada interval 3,51 - 4,00 dan termasuk tingkat kualifikasi Cum Laude; (3) Terdapat pengaruh antara mentoring dosen pembimbinga akademik terhadap prestasi akademik mahasiswa program studi pendidikan ekonomi anagkatan 2016 STKIP Pembangunan Indonesia. Hal ini ditunjukkan dari nilai sig. 0,007 $<0,05$ maka Ha diterima dan Ho ditolak.

Saran dalam penilitian ini adalah: (1)

Kepada Lembaga : karena pentingnya mentoring dari dosen pembimbing akademik untuk mahasiswa, diharapkan pimpinan lembaga selalu mengadakan evaluasi terhadap kinerja dosen pembimbing akademik; (2) Kepad dosen pembimbing akademik diharapkan untuk meningkatkan evaluasi hasil kuliah semseter sebelumnya serta memberikan bimbingan akademik untuk semester selanjutnya setiap awal semester. Selain itu, Penasehat Akademik juga harus selalu memantau keadaan mahasiswa bimbingannya minimal 2 kali dalam satu semester; (3) Kepada mahasiswa diharapkan memanfatkan mentoring dosen pembimbing akademik dengan baik dan tidak hanya pada awal semester saja. Mahasiswa juga diharapkan lebih terbuka dalam menyampaikan permasalahan yang dihadapi sehingga dosen pembimbing akademik dapat membantu secara optimal

\section{DAFTAR RUJUKAN}

Moh. Zaiful Rosyid, Mustajab, Aminol Rosid Abdullah. 2019. Prestasi Belajar. edisi pert. Literasi Nusantara.

Muchson, M. n.d. Statistik Deskriptif. Guepedia.

Nasution, S. 2012. METODE RESEARCH (Penelitian Ilmiah). Jakarta: PT. Bumi Aksara.

Pranatasari, Fransisca Desiana. 2014. "PENGARUH MENTORING DOSEN PEMBIMBING AKADEMIK."

Siregar, Syofian. 2017. STATISTIKA TERAPAN UNTUK PERGURUAN TINGGI. Jakarta: KENCANA. 
Phinisi Integration Review. Vol 3(2) Agustus 2020

Sudarmanto, R. Gunawan. 2013. STATISTIK TERAPAN BERBASIS KOMPUTER (Dengan Program IBM SPSS Statistics 19). Jakarta: Penerbit Mitra Wacana Media.

Suprihatin, Titin. 2016. "Kepuasan Mahasiswa Terhadap Pembimbing Akademik." Proyeksi 11(1):36-45.

Suprihatin, Titin. 2017. "Prestasi Akademik
Ditinjau Dari Model Bimbingan Akademik." Prosiding Temu Ilmiah X Ikatan Psikologi Perkembangan Indonesia 321-30.

Susilowati, Tutik. 2008. "PERAN DOSEN PEMBIMBING AKADEMIK (PA) TERHADAP PRESTASI BELAJAR MAHASISWA (Sudi Kasus Di Program Studi Pendidikan Ekonomi Jurusan P.IPS FKIP)." MIIPS 2:57-65. 